\title{
AN ANALYSIS OF FEMINISM ISSUES IN VERONICA ROTH'S DIVERGENT: A READER RESPONSE STUDY
}

\author{
Andi Darmawanto ${ }^{1}$, Mas'ulah $^{2}$, \& Ari Setyorini ${ }^{3}$ \\ Muhammadiyah University of Surabaya, Andidarmawanto.official@gmail.com
}

\begin{abstract}
Since this research mainly uses a reader response approach in which the response from the readers becomes the main data to analyze, two College students with different background and gender become the subject of the research to contribute their interpretation. Moreover, they are engaged in WhatApp group as a mean to discusse about the issues which become the guide of the research. Futhermore, this research has its focus to scrutinize the response of the readers toward feminism issues in Veronica Roth's Divergent. Beside that, reader-response theory authored by Wolfgang Iser to be the main theory which guides to determine the type of the readers. Their responses transcribed by the researcher are the main data to complete the aim of the research. By utilizing descriptive qualitative method to describe the interpretation, the yield of this research is that the readers interpret the issues of women's leadership, gender discrimination, and independent female in the novel of Divergent by collaborating their background; experiences, gender and prior knowledge as prime-effect on how they interpret.
\end{abstract}

Keywords: Reader-response, Feminism, Divergent

Basically, all human have the equal roles in the society. It means that both gender - men and women have right to engage in all aspects in the public or private life. However, in real situation, women are regarded as the inferior toward men. In other words, men are as the superior who control women. According to Shastri (2014:28) "Women face every kind of discrimination in this society. They are deprived from the basic facilities like education. Women's lives are shaped totally by our customs that are centuries old. They had many boundation also." As the impact, women cannot do what they want comfortably as their right to manage their life.

Regard of the phenomenon that talks about gender, feminism may be able to be adopted in analyzing or eliciting the issue related to the gender especially to women. Feminism itself at least in Bowen and Wyatt's view cited in Sarikakis at all is that no precise definition of it, yet a number of brief statements can ease in understanding - feminism focuses on women's life (2008:505). In fact, that view is caused by some labels belong to feminist; liberal, radical and Marxist-socialist etc. for those labels have their own different focuses. Moreover, feminist is the one who contends that women got discriminations for their sex then make them effort to negate those dissatisfactions in social. Based on Delmar "a feminist is someone who holds that women suffer discrimination because of their sex, that they have specific needs which remain negated and radical change (some would say a revolution even) in the social" (1984:8). Furthermore, according to Hook (1984:24),

"Feminism is a struggle to end sexist oppression. Therefore, it is necessarily a struggle to eradicate the ideology of domination that permeates Western culture on various levels as well as a commitment to reorganizing society so that the self-development of people can take precedence over imperialism, economic expansion, and material desires."

Feminism issues itself is not merely revealed in a real life yet also can be adopted in the story in which story contained in literary work. From that phenomenon, the product of literary work can be 
regarded as the way to deliver some issues especially feminism issue representing the real life though it comes from author's imagination. Yet, those imaginations must be influenced by some things related to the author's life, feeling and so on or it is author's criticism against his/her life in the form of writing.

Considering that the story can depict a real situation in the form of text, novel is a part of literary work in the case of epic literature. According to Lukacs, novel is a great epic literature form which shows historico-philosophical realities which are faced by the author (1920:14). Then, what it meant by novel itself - based on Eagleton's view, novel is a kind of prose points out the common life which contains a number of values and conflicts (2005:4). It means that novel is a genre of prose which serves a long story or dialogue that emerge some conflicts in it.

Moreover, novel is one kind of long story that occasionally brings feminism issue up. It is therefore several readers who read the novel do not understand if it contains some issues especially feminism. As the result, while they enjoy reading, unconsciously they are influenced by the ideology related to the women's struggle. Moreover, they will gain the ideology and give their opinion depends on what they know. Meaning that every readers has their own way whether they just follow the story or they follow and give their ideology based on their background and experiences. Based on Iser's view cited in Selden (1985 A Reader's Guide to Contemporary Literary Theory, 112), Readers are divided into two namely implied readers and actual readers. First reader means whom responses are constructed by the text and influenced a reader to read in certain way while actual reader receive mental meaning when reading, but it is modified by the reader's experience and knowledge. Thus, reading activity of novel will be both attractive and fruitful.

Due to the fact that the readers give their responses after reading novel even they interpret the novel through their own ideology or understanding, feminism issues finally depicted in their responses toward the text/ novel. Reader-Response theory focuses on the reader's interpretation; of course, different readers have different interpretation based on their background. As stated by Klarer (2004:903) that Reader-Response theory is focus on the reader's point of view to give a meaning toward a text that might depends on education, age, gender, nationality and the most possible is on the reader's competence and experience. It means that there is interaction between the reader and the text. As the result, the reader is vastly considered as the important as the researcher in meaning the text. It is thus, Veronica Roth's Divergent is such very attractive novel to be discussed in finding the issues related to women's struggle to gain their right by applying a reader-response theory.

"Divergent" is written by Veronica Roth as a young adult novel which focuses to the readers in the age of 18 - 31. It debuted in 2011 at number six on the New York Times best-seller list and nominated as the Favorite Book category for a kids' Choice Award in 2015. Beside that, it can be said that Divergent emerges a lot of issues especially feminism seen from some characters. Hence, this novel has attracted many people to read. There are a lot of readers who has published their response in their blog. One example taken from Lady Bee which is published on April, 9th 2014 entitled Divergent: A book analysis of what makes a strong female character in (https://disruptingdinnerparties.com/2014/04/09/divergent-book-analysis-of-strong-femalecharacters/). She states that Divergent is a young adult novel tells about the strong female character who are brave to upset an unjust system. She further states that female strong female is a woman who can secure herself and have a willing to stand up for something right and decide her own destiny.

Above all, in contact to feminism issues in novel of Veronica Roth's Divergent, as far as researcher's view, a research about reader's response using feminism perspective in Veronica Roth's Divergent has not been done yet. So, the researcher then formulates one research question to be the guide in eliciting the readers' interpretation toward feminism issues such as women's leadership, gender descrimination and independent women in Veronica Roth's Divergent namely How do the readers interpret the issues of feminism in Veronica Roth's Divergent? 


\section{Method of the Research}

The approach of an analysis on the work of Veronica Roth is observed through readers' perspectives who analyze literary work. It means that reader-oriented approach that also known as the receptive theory, reader-response theory, or aesthetic reception will be utilized in this research. According to Lobo that centers his study on Wolfgang Iser's phenomenological approach, Readerresponse theory is mainly about the relation between the reader and the text to interpret the text, (2013:13). Moreover, the interpretation of the text depends on the reader's knowledge, experience, age and gender.

Additionally, the research mainly uses descriptive qualitative. This means that this research analyzes the data by describing the data in detail. Beside that, this research is also qualitative for the data analyzed is not in the form of number (or numeric) but it is in the forms of words, phrases, or utterances or sentences.

The statement above is supported by Creswell. He contends that the qualitative research explores and understands the group or individual meanings in social or human problem in which the data is in the form of words and it deals with case studies (2009:11). Another view is from Tylor et al. "Qualitative research is inductive. Qualitative research develops concepts, insights, and understandings from patterns in the data rather than collecting data to assess preconceived models, hypotheses, or theories"(2016: 08). Furthermore, the intention of qualitative research is to develop concepts used in boosting the understanding of the social case which accentuates on the meanings, experiences, and views of all participants (2006: 04).

From some explanations above can be deduced that reader-oriented approach and qualitative method of the research is used to analyze and describe the social phenomenon or human problem in the form of words, and not in statistical form. Beside that, in finding the issues of feminism on Veronica Roth's Divergent, the approach used to analyze the response from the readers who have read the novel that may contain some issues of feminism. It is considered by the researcher as the proper method used to gain the purpose of this study.

Moreover, In selecting the subject, the researcher must know type of Divergent novel which is one of young adult novels authored by Veronica Roth. It is thus, the participant also should be based on the age of young adult novel namely 18-31. Based on report from Pew Research Center, "a young Adult refers to an 18 to 31 years old" (2013:03). Beside that, the subject of this research also refers to both genders: one male as the second reader studies at Airlangga University focuses on Anthropology department and another one is female as the first reader from Muhammadiyah University of Surabaya who focuses her study on English education department. From those different background, the researcher aim to elicit whether they have different interpretations on female action. Furthermore, another reason why the researcher select one male and female is because the researcher has a feeling that male will have different interpretation which is in contrast to male's thought. Perhaps, female will agree with the effort of women to gain their equality toward men while men disagree, or vice versa. Moreover, the participants will be engaged in the group of WhatApp Application to respond the question delivered by the researcher because this research mainly uses online focus group discussion as a technique to collect the data.

\section{Finding and Analysis}

Regard of the interpretation needed, the researcher then decides some points related to the issues of feminism to be the guide in delivering the questions in the group with the readers. Meaning that the questions are mainly about three issues of feminism such as independent female, women's leadership and gender discrimination thought they do not ask directly. 
Furthermore, the readers itself are divided into two types based on how they interpret what have been read. According to Iser cited in Selden (1985:112)

"Readers are divided into two namely implied reader and actual reader in which the first reader is defined as whom responses are constructed by the text and influenced a reader to read in certain way while actual reader receive mental meaning when reading, but it is modified by the reader's experience and knowledge."

It means that in interpreting what comes to the readers' mind after reading the story, there are some things that are considered as the prime effect on how the readers' interpret their perception toward the novel read. In this case, the researcher uses it to know whether the selected readers are regarded as the implied readers or as the actual readers.

Below are the finding and the discussion about the issues of feminism which are revealed in group discussion especially in the readers' response that mainly focus on three points decided by the researcher.

\subsection{Reader's Response toward the Feminism Issues in Divergent.}

In Divergent, the society is divided into factions based on the human virtue. All of people who are in sixteen must choose one of the factions and stay in for the rest of their life. The people in sixteen years absolutely are not only the men but also women and they are able to choose their own faction. In this case, several women decide their faction where it is very hard, it is dominated by the men, it is like the faction that is specifically for men not women. Moreover, the story such centers that case in which the women out of the faction where it is should not be chosen by the women. It is thus, the story such tells about their struggle.

In this situation, women proof that they can be a dominance such man in public where society always think that women can do nothing for their life. In other word, they are always thought as the person who must stand under the men for the stereotypes on women are like weak, obedience and so forth which give disadvantages for them. While in the novel, those thought are really wrong. The women are depicted in contrast to that view. As interpreted by the readers who read the novel that the story of Divergent tells mostly about women as dominance person.

First reader : That is good story that tells about the woman who protects and defends herself. The story is so inspiring, especially for women that they could be better than before.

Based on the above opinion uttered by the first reader, the story of the novel talks about woman who the women are actually able to save herself without helping by the men. It means that the stereotype of women is not that correct. Moreover, she also contends that women could be better before. It means that the struggle of woman to protect herself is good value shows that they have power and not as weak as general thought before. Furthermore, in the utterance "that is good story that tells about the woman" uttered by first reader which has an implied meaning caused her gender as woman. The implied meaning is that the reader is really proud that the story is about the struggle of women. She seems like to support the story in order that all people know that the women have right such as protecting herself. In means that it can inspires all people especially for women. That idea can be seen also from "so inspiring", it such indicates that the first reader specifically is inspired after reading the novel because she is 
also the woman that need a hard effort for her right in real life. She need to works not only in the house as the stereotype on women in general. However, the idea stated by the second reader may have similar opinion that the novel mainly relates about women and her life.

Second reader : yeah you know... that story tells about a woman that really out of the box, struggle for her life and her surround. The women that other think can't life cause she's different from the others and dangerous for surround.

Above opinion more asserts that he thinks the story tells about how woman do struggle for her life and out of the judgment that woman cannot live with different virtue. The virtue deems as the dangerous virtue for surround as the result her presence is not acceptable by the society. Meaning, the social value eliminates her to participate in the society for that reason. However, through her struggle to do best for surround, help other people without thinking herself, she proves that the woman can take in hand her problem then it is eradicate the ideology. This idea - at least in Berg cited in Hook, feminism talks about woman's struggle to liberate from the society's oppression. He further states that it is about woman's right that needs to be accepted to individual conscience and judgment. (1984: 24).

In fact, it affirms that women can do what they want without thinking the society's oppressive restriction fallen on them, they can decide their own way. Women decide their own way by choosing the faction, Dauntless to show that the women can be as men, women can do what men do. Besides that, the story also shows a lot of action acted by the women. It means that women are the domination in the story.

In this case, the readers mostly have similar interpretation that the author's background influences plot of the story in which the story is dominated by the women. It can be seen from their interpretation below:

Researcher : Based on your opinion, why does the author choose the women as the dominant character in the story?

Second reader : For me... maybe it's because the author wants to make the reader or watcher realize that women also have a right to fight for life in her way.

First reader : I think because of the writer is woman, so she wants to make a character about the power of woman she makes the woman as the main character to be dominant in the story. She thinks that woman is important and can make any change in the world.

Second reader just think that the goals of the story based on the author is to show the reader or the audience about the women's right for her life, how their life should be depends on themselves without any involvement or restriction from men. Meanwhile that opinion is added by the response from first reader shows the story is affected by the author's gender namely women, as the yield, the plot of the story is dominated by the women to show that not only man who have a power yet also woman have. It is thus, their struggle reveals that the story is telling about the feminism. Beside that, first reader states that can make any change in the world which shows that it is such hope from her in order that women included herself should be like that one, should save their right and should be able to do thing better for life. 


\subsubsection{How the Readers' Interpretation toward Women's Struggle}

\subsubsection{Reader's Interpretation on the Issues of Independent Female Character}

Beatrice or Tris is the center of the story who regards as the character that shows a lot of issues of feminism from her action, her struggle, and so forth. The action or the struggle that should not be done by the woman. Tris is one who chooses Dauntless faction that is specifically for men. Beside that, Dauntless person should be brave, no hesitant feeling. Moreover, all persons who participate in this faction should follow the training to complete the stipulation to be real Dauntless person and for who cannot complete it, they will rejected as part of them. They have to be able to shoot the target by the gun without missing, they have to be able to fight and not depend on other people. In this case, Tris' willing to leave her family's faction shows that woman have right to determine her destiny, she can determine her sex role and to be independent by choosing her faction to be part in.

"I suggest," Tori says, "that you go home. You have a lot of thinking to do, and waiting with the others may not benefit you."

"I have to tell my brother where I'm going."

"I'll let him know."

I touch my forehead and stare at the floor as I walk out of the room. I can't bear to look her in the eye. I can't bear to think about the Choosing Ceremony tomorrow.

It's my choice now, no matter what the test says. Abnegation. Dauntless. Erudite. Divergent. (Divergent, Chap 3)

From above quotation, it can be seen that Tris have a willing to be independent. She does not want to be suggested or forced by other people even they know well what will happen on her. However, Tris bears what other people suggest or what the aptitude test says on her virtue because she thinks that join in one of the factions is her right. Beside that, Tris and her family has same think that the test has no meaning to determine whether she is dauntless, erudite and so on. it also can be seen from the following quotation.

Caleb and I climb the stairs and, at the top, when we divide to go to our separate bedrooms, he stops me with a hand on my shoulder.

"Beatrice," he says, looking sternly into my eyes. "We should think of our family." There is an edge to his voice. "But. But we must also think of ourselves."

For a moment I stare at him. I have never seen him think of himself, never heard him insist on anything but selflessness.

I am so startled by his comment that I just say what I am supposed to say: "The tests don't have to change our choices."

He smiles a little. “Don't they, though?” (Divergent, chap. 4) 
furthermore, the struggle women to gain their right is like what Tris does namely deciding her own destiny or individual lives without mind something that force her to change her choice. This idea stands in line with Hook's quotation on Houston conference report that women determines their destiny, of their world, notion, family, and individual lives as a human right a full voice and role of women (1984:20).

In contact to the quotation from the work, the interpretation of the readers based on the novel Divergent indicates that the readers have similar opinion that women have right to determine their choice to be independent. It can be seen from the following interpretation from first reader:

First reader : Women are more dominant in the story because the main character of the story is Tris. It's about Tris realize that she is Divergent and her struggle to join her favorite faction (Dauntless)

Although she is very near to her mother, she does not show her obedience to her mother by staying in her family's faction as her mother suggested. However, she still firms to fulfill her desire to decide her favorite faction, Dauntless. In this case, Tris Prior has a feeling to be independent as new one in sixteen. She determines her own destiny thought she must leave her family to her new faction. Her desire to be independent by deciding her own destiny is supported by Berg's idea cited in Hook that feminism is about the woman's freedom to decide her fate and not depend on the others of her life. (1984:24)

Researcher : What do you think about the main character, Tris Prior?

Second reader $\quad$ : Tris Prior...? she's very stubborn if you want say. But, she's kind, never want harm anybody that she love. And I think, she makes her burden become the wall that separates her with her dream, destiny, etc.

First reader $\quad$ : After I read the story, Tris is an independent, strong, and intelligent woman. She chooses her own way to be someone that she wants. She defends her identity until the end of the story. She is brave too. She is never afraid to stand for something right. As the role of protagonist, she is good hearted and helpful. She can be the role of modern woman in this era because of the way she behaves.

"she's kind, never want harm anybody that she love. And I think, she makes her burden become the wall that separates her with her dream, destiny, etc." From that utterance, the second reader wants to tell that Tris always help other people around her. She does not want them to be hurt though the burden will be on her back. It indicates that woman can also protect other people included man, and not always to be protected by the man. This idea absorbs the definition of patriarchal system in which the women are controlled by the men as the domination. According to Walby, patriarchal is a system of domination where the men bring about the instrumental roles while the women as the expressive one (1990:63). 
Besides that, Tris regards as tenacious woman who firms to take what she want though she should sacrifice her dream, fate and so forth. Furthermore, in the words "She's very stubborn" means that the second reader dislike a people with this characteristic. It can be seen from his background that he is an active one participating in some organizations which build his character to not be stubborn one. In other response, he also utters same expression which more affirms that he does not like the people with this characteristic.

Second reader $\quad$ : For me about Jeanine: stubborn, and also she can make me want to kill her just like Tris wants to stop her.

In fact, it is clearer that the response is related to his own characteristic. The second reader shows his characteristic through the utterance "But, she's kind, never want harm anybody that she love". it can be said that the characteristic owned by himself which is like what he says, loving other people.

In the same case, the first reader also has similar interpretation which can be seen from the utterance "Tris is an independent, strong, and intelligent woman. She chooses her own way to be someone that she wants. She defends her identity until the end of the story". From that utterance, the first reader directly says that Tris is an independent woman who tries to be herself with her own way and defends her identity though many people hate her even underestimate her for she come from Abnegation faction which virtue is an opposite to Tris in this time.

From those two responses based on both readers, there is a different which may be influenced by their gender. The second reader says something that it is actually disagree to what Tris do as the main character. He thinks that Tris prior is stubborn as woman and easy to do haphazardly even it is not for herself. It can be seen from the utterance "I think, she makes her burden become the wall that separate her with her dream, destiny, etc" while the interpretation of the first reader indicates that the reader do agree. She thinks that Tris is a good woman that can be a pattern for all women whether it is patterned from Tris' action for other people or Tris' behavior. "She is brave too. She is never afraid to stand for something right. As the role of protagonist, she is good hearted and helpful. She can be the role of modern woman in this era because of the way she behaves."

\subsubsection{Reader's Interpretation on the Issues of Women's Leadership}

Since the term leader is always behaved for men, the issues of women's leadership may become a prominent issue for feminist's struggle. This idea - at least in Chandler, in fighting the stereotype on them, women bring their leadership on local, national even global level since 1970s which has yield that their leadership styles are more transformational, participative and inclusive than men's style (2011:01). In this case, it can be said that women are able to be a leader even their styles or actions to be are better than men. Furthermore, feminist theory has discussed about women's liberation movement contained in second wave of feminist. According to Chandler, the increase of female leaders catalyzed by the women's liberation movement (2011:04). This idea is supported by Carter that the second wave much influenced by various liberationist movements focuses on women's biological difference toward men. 
In the novel, Jenine is one of the women who becomes the leader of Erudite faction where the faction is only for who have as smart or intelligent thinking. In other words, Erudite is such an association for people with critic, intelligent and clever thinking. In the story, Jenine is a woman that has an authority to lead the community with her way even she is enthusiastic to control all of the faction. This idea is an absolutely related to the feminist where the women try to be dominant then men especially in the term of politic.

Researcher : Is only Tris who has struggle in the story? Or any else that show women is the dominant in the story?

First reader : Beside Tris, I think that Jeanine is a woman who wants to be a dominant person that takes control all of the factions. She is a woman but she is capable to be a leader and makes the factions as she wants to.

From above idea delivered by first reader, it indicates that the power of women is not only when she produces a baby, takes care of the baby, or goes after the husband but also she can be a leader who controls the community. In this case, the reader shows that Jeanine is a woman with a huge dream that lead her to be a leader. What she say such good thing for others. It is seen from the utterance "She is a woman but she is capable to be a leader and makes the factions as she wants to". Absolutely, what she wants is to control all of the community and bent down to her. Beside that, Jenine shows that she has capability to be a leader by having a mision, and having strategy to gain the purpose namely to control all factions. According to Bass' statement cited in Gini and Green, a leader is a person who has vision and mission to change, develop ideas and strategies for the others to accomplish the purpose and goal which the organization strives (2013:05). From that idea, Jenine do seems be a leader. She can organize other people in Erudite and some in Dauntless to accomplish her purpose. Moreover, behind the utterance "She is a woman but she is capable to be a leader" has own meaning. The word "but" means that the first reader does disagree if many people do not believe on the capability of the women especially to be a leader. She seems to prevent that idea that women should not be underestimated especially on their capability.

\subsubsection{Reader's Interpretation on the Issues of Gender Discrimination}

The term gender discrimination which refers to both men and women whose roles are created by the society differently. Women are constructed to be weaker with the roles such as going after family. According to Shastri, gender discrimination is generally for women who are considered as the weaker side in the society as the result they have roles such caring house, children, husband and so on (2014:27). From that statement, it can be concluded that the term discrimination is such as underestimating the capability belong to women. However, it is happened so to Tris as the main character in the novel.

“Ooh. Scandalous! A Stiff’s flashing some skin!"

I lift my head. "Stiff" is slang for Abnegation, and I'm the only one here. Peter points at me, smirking. I hear laughter. My cheeks heat up, and I let my sleeve fall. (Divergent, chap. 6) 
Based on the quotation above, it indicates that Tris gets mockery from peter because of the stereotype on her previous faction where the faction is regarded as the stiff. It thus, Tris also gets that mockery which can be seen from "Peter points at me, smirking". According to Kaliouby et al. "The face is one of the richest sources of communicating social and emotional information, and is capable of generating tens of thousands of expression, including asymmetric ones". One of the asymmetric is asymmetric smile such as smirking. In this case, Smirking codes that she underestimates her as the woman can do nothing based on slang "Stiff". However, that discrimination does not cause her to give up or feel inferior, but it is in contrast to that. Tris is not hesitant to show Peter and others that she is not stiff and has an aggressive or brave as men. It is indicated by the following quotation:

This is a scare tactic. I will land safely at the bottom. That knowledge is the only thing that helps me step onto the ledge. My teeth chatter. I can't back down now. Not with all the people betting I'll fail behind me. My hands fumble along the collar of my shirt and find the button that secures it shut.

After a few tries, I undo the hooks from collar to hem, and pull it off my shoulders.

Beneath it, I wear a gray T-shirt. It is tighter than any other clothes I own, and no one has ever seen me in it before. I ball up my outer shirt and look over my shoulder, at Peter. I throw the ball of fabric at him as hard as I can, my jaw clenched. It hits him in the chest. He stares at me. I hear catcalls and shouts behind me.

I look at the hole again. Goose bumps rise on my pale arms, and my stomach lurches. If I don't do it now, I won't be able to do it at all. I swallow hard. I don't think. I just bend my knees and jump. (Divergent, chap. 6)

Above quotation shows the struggle of Tris to end the discrimination on her. first struggle that is done by Tris is by being first jumper which reveals that she is not that stiff even braver that others.

However, how the reader interprets their response toward this problem is such how the author interprets the idea to deliver the story. It can be seen from the following quotation based on the discussion result:

Researcher

Second reader

First reader
: Oke, if you are on Tris side. So what do you think about Peter who always forces her to back to her previous faction and underestimates her that she can do nothing as woman?

: If I am on Tris side, I show him that what he thinks about is absolutely wrong.. And kind of terrible thinking.

: Maybe some men think that they are better than women. They think that only men have power. And peter is one of those men. Peter thinks that Tris is a woman. Women are weak and do not deserve to be a Dauntless. 
In the first time Tris come in Dauntless faction, she gets discrimination. She is underestimated by others especially from Peter who mocks her as clumsy and he asks back to her previous. However, the readers have no idea such peter who underestimates her. It can be seen from the utterance uttered by the second reader "If I am on Tris side, I show him that what he thinks about is absolutely wrong.. And kind of terrible thinking". The second reader affirms that he does not think that Tris is like what Peter says. On the top of that, he imagines as if he were Tris, he shows his capability to Peter which results that his thought of Tris is really wrong. Moreover, Tris can show that she can what men can do while in the Dauntless even better than men. It means that women are not as that weaker as what the society treat to them, only to take care of the family.

Furthermore, the first reader mostly has similar opinion that woman should not be underestimated as weaker. It can be seen from "Maybe some men think that they are better than women. They think that only men have power" that the first reader does not like that the term discrimination is only for women who are regarded as weaker, no power on them and so forth. In fact, Tris' struggle makes many people around believe that Tris is a woman with much power that is usually done by the men. The power to lead the people, the power to decide his own way, the power stand in something right and so forth. Beside that the first reader shows her idea that she does not stand in line with peter that always underestimates Tris.

In this case, between first reader and the second reader has little difference which is influenced by the knowledge of the readers. The first reader who studies in English department know well how's the stereotype on women which becomes the discrimination for them. It is thus, she claim that women are not like what men think, and women can work outside not only caring the family. While the second reader is like showing his logic and emotion when there is a problem like that one. It is caused his knowledge about feminism is only inserted a few by his lecture as an activist woman when he learnt an anthropology subject. Beside that, his idea of emotion is also caused he discerns to his activist woman who is his lecture. As the yield, his interpretation toward women's discrimination is different from the first reader.

In accordance to those responses uttered by the readers, it can be determined that both of the readers are containing in actual readers whose responses are influenced by their gender, characteristic, or knowledge of how they interpret their own perception toward the issues of the text. This idea refers to Iser's theory of Reader Response that has been explained in begining of chapter IV. Hence, actual readers mean that the readers create their own meaning toward the text through collaborating the real meaning with their gender, prior knowledge and experience. Moreover, based on Iser's view cited in Shi, to create the potential meaning, the reader and the text are two component that cannot be detached in order that the reader involves his/her feeling to interact with the text (2013:984).

\section{Conclusion}

Reader-response is one of theories that gives deeply understanding about the reader. Moreover, it talks about how the readers interpret what they have read whether they are as implied readers or actual readers which can be seen from the response belong to them. It means that in understanding the story 
which contains many issues, sometime, people will have different perception from the author, or it can be similar so, it can be caused of their prior knowledge, experience and so forth.

As to which the research was conducted by the aim whereof be portrayed in one question namely "how do the readers interpret the issues of feminism in Veronica Roth's Divergent?". The research question was successfully answered that in interpreting the issues of feminism such women's leadership, gender discrimination and independent female, the readers collaborate what actually meant by the text of the novel with their prior knowledge, gender and experience, it is thus, the readers are classified as the actual reader based on the definition from Iser.

\section{References}

Chandler, Diane. (2011). What Women Bring to the Exercise of Leadership. Journal of Strategic Leadership. Vol. 3 (2): pp. 1-12

Creswell, John. (2014). RESEARCH DESIGN Qualitative, Quantitative, and Mixed Methods Approaches. Thousand Oaks, California: SAGE Publication, Inc.

Eagleton, Terry. (2005). The English Novel: An introduction. USA: BLACKWELL PUBLISHING

Gao, Haiyan. (2013). Reflection on Feminism in Jane Eyre. Theory and Practice in Language Studies. Vol. 3 (6): pp. 926-931

Gini, Al and Green, Ronald M. (2013). Theory and Practice in Language Studies. Vol. 3 (6): pp. 926931

Gini, Al and M. Green. (2013). 10 VIRTUES OF OUTSTANDING LEADERS: LEADERSHIP \& CHARACTER. UK: WILEY-BLACKWELL

Hooks, Bell. (1984). FEMINIST THEORY from margin to center. United State: South End Press.

Klarer, Mario. (2004). AN INTRODUCTION TO LITERATY STUDIES Second edition. New York: Routledge

Lobo, Alejandra Giangiulio. (2013). Reader-Response Theory: A path Towards Wolfgang Iser. Pp. 1330

Lukacs, Georg. (1920). The Theory of The Novel. London: The Merlin Press

Pew Research Center. August 1, (2013). A Rising Share of Young Adults Live in Their Parent's Home. Page 3

Sarikakis, Katharine, et al.(2008). FEMINIST THEORY AND RESEARCH.

Selden, R. (1985). A Reader's Guide to Contemporary Literary Theory. Great Britain: THE HARVESTER PRESS LIMITED

Shastri, A. (2014). Gender Inequality and Women Discrimination. IOSR Journal Of Humanaities and Social Science. Vol. 19 (11): pp. 27-30

Taylor, S, \& j. Et al. (2016). Introduction to Qualitative Research Methods fourth edition. Canada. John Wiley \& Sons, Inc.

Walby, Sylvia. (1990). Theorizing Patriarchy. Oxford. Basil Blackwell Ltd. 